Research Article

\title{
Observational study of laparoscopic closure of peptic ulcer perforation in rural population
}

\author{
Sudhir B. Deshmukh ${ }^{1}$, Kuldeep Sharma ${ }^{2}$, Meghraj J. Chawada*
}

${ }^{1}$ Professor and HOD, ${ }^{2}$ PG Student, ${ }^{3}$ Associate Professor, Department of General Surgery, S. R. T. R. Government

Medical College, Ambejogai, Maharashtra, India

Received: 11 May 2016

Accepted: 14 May 2016

\section{*Correspondence:}

Dr. Meghraj J. Chawada,

E-mail: dr.meghrajchawada@gmail.com

Copyright: ( $)$ the author(s), publisher and licensee Medip Academy. This is an open-access article distributed under the terms of the Creative Commons Attribution Non-Commercial License, which permits unrestricted non-commercial use, distribution, and reproduction in any medium, provided the original work is properly cited.

\begin{abstract}
Background: Peptic ulcer perforation is one of the common surgical emergencies which need immediate surgical intervention. For many years, the routine upper laparotomy still seems to be the routine treatment of perforated peptic ulcer. The improvement of technology and an increase in laparoscopic experience have been central to the development of laparoscopic surgery. Objective of the study was to assess the efficacy of laparoscopic approach in perforated peptic ulcer repair.

Methods: The present study is based on the analysis of 30 cases of peptic ulcer perforation admitted to our hospital between 2013 and 2015. Post-operative mobilization of every patient was done after 6 hours and $\mathrm{H}_{2}$ receptor antagonist or proton pump inhibitor was given with fluid, antibiotics and nasogastric suction. Post-operation analgesics (IV tramadol \pm IM diclofenac SOS) were given according to visual analogue score (VAS).

Results: $22(73.33 \%)$ patients were having duodenal ulcer perforation and $8(26.67 \%)$ were having gastric ulcer perforation. Postoperatively out of 30 patients, 18 patients were presented with VAS 4. The most common complication was trocar site infection seen in 2 patients $(6.6 \%) .3$ patients $(10 \%)$ needed to covert laparoscopic procedure into open procedure due to large size of perforation $(>10 \mathrm{~mm})$. The hospital stay varied from 4-16 days.

Conclusions: Laparoscopic repair of perforated peptic ulcer is safe and reliable technique. It gives the patient all the advantages of laparoscopic surgery with accepted post-operative morbidity and mortality rates. However, laparoscopic closure of the perforation is technically demanding. It should be considered as a good choice in the presence of reasonable laparoscopic skills and experience. It had less postoperative pain and reduced analgesic usages, shorter postoperative hospital stay and early return to oral feeding and normal daily activities.
\end{abstract}

Keywords: Peptic ulcer, VAS, Hospital stay

\section{INTRODUCTION}

Since the advent of $\mathrm{H}_{2}$ antagonists, supplemented recently by omeprazole, the frequency of the use of surgical procedures for intractable peptic ulcer has decreased dramatically. ${ }^{1}$ The use of simple closure of perforated peptic ulcer, in combination with postoperative use of $\mathrm{H}_{2}$ blocking drugs, also has been increasing. ${ }^{2}$ Laparoscopic surgeries have revolutionized the practice of cholecystectomy and have led to the development of a wide range of laparoscopic surgical procedures. Progress currently can be said to include this minimally invasive surgical procedure for perforated peptic ulcer.

Peptic ulcer perforation is one of the common surgical emergencies which need immediate surgical intervention. ${ }^{3}$ For many years, the routine upper laparotomy still seems to be the routine treatment of 
perforated peptic ulcer. ${ }^{4}$ The improvement of technology and an increase in laparoscopic experience have been central to the development of laparoscopic surgery. Laparoscopy has fast gained wide acceptance by surgeons for elective cases, as well as for emergency situations, such as acute cholecystitis, appendicitis. Laparoscopic repair for perforated duodenal ulcer was first described in $1990 .^{5}$ It has not only allowed identifying the site and pathology of perforation, but also allowed closure of the perforation with better peritoneal lavage than in the open repair. Laparoscopic repair of perforated duodenal ulcer has many advantages as less post-operative pain without long incision, faster recovery and shorter hospital stay. ${ }^{6,7}$ Treatment for perforated ulcer ranges from conservative treatment (Taylor's approach) to radical surgery (vagotomy, gastrectomy). However, with the use of powerful acid suppressing medication and the eradication of Helicobacter pylori, the need for radical surgery in emergencies has sharply declined. The surgical technique most often used is closure of the perforation combined with extensive peritoneal lavage. Repair of duodenal perforation by Graham patch plication (as was described in 1937) represents an excellent alternative approach. Perforated duodenal ulcer is a surgical emergency. In 1990 Mouret et al reported the first laparoscopic suture-less fibrin glue omental patch for perforated duodenal ulcer repair. ${ }^{8}$ The first successful laparoscopic suture repair for perforated peptic ulcer was described by Nathanson et al also in $1990.9,10$ Soon after that the laparoscopic approach became a widespread procedure. Laparoscopic repair of duodenal perforation is a useful method for reducing hospital stay, complications and return to normal activity. Treatment for perforated ulcer can be performed laparoscopically in $85 \%$ of cases, making it possible to avoid a median laparotomy which can lead to wound infection and late incisional hernia. With better training in minimal access surgery now available, the time has arrived for it to take its place in the surgeon's repertoire. Some basic principles must be followed. They include intravenous antibiotic therapy before insufflation, intra-abdominal pressure between 8 and $12 \mathrm{mmHg}$ and initially performing peritoneal lavage.

So, we conducted this study to assess the efficacy of laparoscopic approach in perforated peptic ulcer repair.

\section{METHODS}

Resuscitation in emergency room (ER) with intra venous fluids, Foley catheter for output monitoring and Ryle's tube for nasogastric decompression are inserted, broad spectrum antibiotics to be administered, electrolyte disturbance if any corrected. After stabilizing the patient in ER and having done the above mentioned investigation patient shifted for definitive procedure (laparoscopic closure) with written informed with valid consent.

Patient placed on the operating table with the legs in stirrups. The knee slightly bent and the hips flex (10 degree). The operating table titled head up approximately
15 degree. The surgeon stands between the patient legs. The camera surgeon was on the right side of patient and assistant surgeon on left side of patient. Four ports are then inserted $(10 \mathrm{~mm})$ port is placed in umbilicus a $(5-10$ $\mathrm{mm})$ port inserted in right upper quadrant $(8-10 \mathrm{~mm})$ from mid line another $(5 \mathrm{~mm})$ port in left upper quadrant another $(5 \mathrm{~mm})$ port is placed at the right subxiphoid region to retract the quadrate lobs of liver. Telescope introduced at $(10 \mathrm{~mm})$ umbilical port diagnostic laparoscopy was done later on whole abdomen should be irrigated and aspirated with about 10 liters of saline mixed with antibiotics. Each quadrant is cleaned methodically starting at the right upper quadrant, going to the left, moving down to the left lower quadrant and then finally over to the right. Special attention should be given to the vesico rectal pouch. Three interrupted stitches are placed and kept without tying the mid line stitch passed through ulcer while another two of them cranial and another one caudal to perforation.

The omental flap is mobilized with intact blood supply is placed over perforation and held in place by grasper in the epigastria port which is also used for liver retraction are then tied over omental flap which completely seal perforation using suture material vicryl (2-0). Through peritoneal lavage is then given with saline irrigation and suction special attention is given to supra hepatic, sub hepatic, left sub diaphragmatic space, and pelvic space. After lavage drain is kept in sub hepatic space close to perforation in case of general peritonitis second drain is left in the pelvis. After that diagnostic laparoscopy was done again then ports were removed, and $(10 \mathrm{~mm})$ ports were sutured, then skin incision was closed.

Post-operative mobilization of every patient was done after 6 hours and $\mathrm{H}_{2}$ receptor antagonist or proton pump inhibitor was given with fluid, antibiotics and nasogastric suction. Post-operation analgesics (IV tramadol \pm IM diclofenac SOS) were given according to visual analogue score (VAS).

\section{RESULTS}

The present study is based on the analysis of 30 cases of peptic ulcer perforation admitted to our hospital between 2013 and 2015. The maximum numbers of cases were in the age group of 51-60 years. A major part of the study group was males. Pain abdomen was the presenting symptom in all cases under study followed by vomiting.

Table 1: Post-operative diagnosis.

\begin{tabular}{|ll|l|}
\hline $\begin{array}{l}\text { Post -operative } \\
\text { diagnosis }\end{array}$ & Number & Percentage (\%) \\
\hline Gastric perforation & 08 & 26.6 \\
\hline Duodenal perforation & 22 & 73.33 \\
\hline Total & 30 & 100 \\
\hline
\end{tabular}


$22(73.33 \%)$ cases were found to have duodenal perforation and rest $08(26.66 \%)$ cases were having gastric perforation (Table 1).

Table 2: Post-operative complications.

\begin{tabular}{|lll|}
\hline Post-operative complications & $\begin{array}{l}\text { Number } \\
(\mathbf{n}=\mathbf{3 0})\end{array}$ & $\begin{array}{l}\text { Percentage } \\
(\mathbf{\%})\end{array}$ \\
\hline Trocar site infection & 2 & 6.67 \\
\hline Sub-phrenic abscess & 1 & 3.33 \\
\hline Port entry complication & 0 & 0.0 \\
\hline Prolonged ileus & 1 & 3.33 \\
\hline Subcutaneous emphysema & 1 & 3.33 \\
\hline Mortality & 0 & 00 \\
\hline No complication & 25 & 83.33 \\
\hline Total & 30 & 100 \\
\hline
\end{tabular}

The most common complication in this series was wound infection which accounted for 3 cases (10\%). Pelvic abscess was seen in 2 cases $(6.6 \%)$. Prolonged ileus was seen in 1 case. Post-operative subcutaneous emphysema was seen in one patient (Table 2).

Table 3: Postoperative course in the hospital.

\begin{tabular}{|l|l|l|}
\hline Post op. day & $\begin{array}{l}\text { Ryle's tube } \\
\text { removal in } \\
\text { no. of patients }\end{array}$ & $\begin{array}{l}\text { No of patients } \\
\text { passed feces. }\end{array}$ \\
\hline Day 2 & 26 & Nil \\
\hline Day 3 & 01 & 25 \\
\hline Day 4 & 02 & 03 \\
\hline Day 5 and 6 & 01 & 01 \\
\hline
\end{tabular}

Out of thirty operated patients Ryle's tube done on postoperative day 2 in 26 patients while in 2 patients Ryle's tube removal done on day 4. 25 patients passed stool on postoperative day 3 while another 3 patients passed stool on postoperative day 4 and another 2 patients passed stool on postoperative day 5 and day 6 (Table 3).

Table 4: Resumption of liquid diet postoperatively.

\begin{tabular}{|ll|}
\hline $\begin{array}{l}\text { Post-operative day of } \\
\text { resumption of liquids }\end{array}$ & Total no. of patients \\
\hline Day 3 & 25 \\
\hline Day 4 & 02 \\
\hline Day 5 & 02 \\
\hline Day 6 & 01 \\
\hline
\end{tabular}

Postoperatively 25 patients started on liquid (oral sips) on post-operative day 3 while another 2 patients resumed on liquids on post-operative day 4 and another 2 patients resumed on liquids on post-operative day 5 while remaining 1 patient resumed on oral sips on postoperative day 6 (Table 4).
Table 5: Resumption of solid diet postoperatively.

\begin{tabular}{|ll|}
\hline $\begin{array}{l}\text { Post-operative day of) } \\
\text { resumption of solid diet }\end{array}$ & $\begin{array}{l}\text { Total no. of } \\
\text { patients }\end{array}$ \\
\hline Day 4 & 25 \\
\hline Day 5 & 02 \\
\hline Day 6 & 02 \\
\hline Day 7 & 01 \\
\hline
\end{tabular}

Postoperatively 25 patients started solid diet on post operative day 4 while another 2 patients resumed on solid diet on post operative day 5 and another 2 patients resumed on solid diet on post operative day 6 while remaining 1 patient resumed on solid diet on postoperative day 7 (Table 5).

Table 6: Post-operative pain analysis.

\begin{tabular}{|lllll|}
\hline $\begin{array}{l}\text { VAS } \\
\text { score }\end{array}$ & $\begin{array}{l}\text { No. of } \\
\text { cases on } \\
\text { post-op } \\
\text { day-1 }\end{array}$ & $\begin{array}{l}\text { No. of } \\
\text { cases on } \\
\text { post-op } \\
\text { day-2 }\end{array}$ & $\begin{array}{l}\text { No. of } \\
\text { cases on } \\
\text { post-op } \\
\text { Day-3 }\end{array}$ & $\begin{array}{l}\text { Type of } \\
\text { analgesia } \\
\text { (IV/IV } \pm \text { IM } \\
\text { sos) }\end{array}$ \\
\hline 0 & 0 & 3 & 21 & Sos \\
\hline 2 & 11 & 21 & 9 & IV \\
\hline 4 & 18 & 6 & 0 & IV \\
\hline 6 & 1 & 0 & 0 & IV \pm IM sos \\
\hline 8 & 0 & 0 & 0 & - \\
\hline 10 & 0 & 0 & 0 & - \\
\hline
\end{tabular}

Postoperatively out of 30 patients 18 patients were presented with VAS score 4, 11 patients were with VAS score 2 and single patient presented with VAS score 6 on post op day 1. On further follow up pain score reduced to 21 patients with VAS score 0 and only 9 were with VAS score 2 on post op day 3 and type of analgesia were chosen according to VAS score (Table 6).

\section{DISCUSSION}

In our study maximum patients having perforated peptic ulcer belongs to older age group (51-60 years) 16 out of 30 patients accounting $(53.33 \%)$ of total patients which is supported by clinical study done by Kenneth Thorsen et al which shows for patients $\geq 60$ years, the incidence increased over 10 -fold. ${ }^{11}$

PN Sreeramulu et al clinical study shows that $57 \%$ of population was among 40-60 years of age group with median age of 52 years which correlates with this literature. $^{12}$ Maximum patients was male 23 out of 30 patient accounting $76.66 \%$ and only 7 were female patients $(23.33 \%)$ which is supported by PN Sreeramulu et al clinical study which shows $80 \%$ preponderance of male patients. ${ }^{12}$ Clinical Study of Bali RS et al shows male preponderance in $68.5 \%$ and supports our study. ${ }^{13}$ 


\section{Presenting symptoms}

Epigastric pain is the predominant symptom in our study presented in all patients and the study of Brian JD et al shows the most common presenting feature of patient with peptic ulcer perforation peritonitis was abdominal pain or discomfort found in more than $70 \%$ of patients. ${ }^{14}$ Jhobta RS et al study also found that the patient of duodenal ulcer perforation usually had a short history of pain starting in epigastrium or upper abdomen along with generalized tenderness and guarding. ${ }^{15}$

Vomiting is another more common symptom presented in $66.66 \%$ of patients.

\section{Localization of peptic ulcer perforation}

In the present $22(73.33 \%)$ patient were having duodenal ulcer perforation and $(26.67 \%)$ were having gastric ulcer perforation. ${ }^{8}$ Clinical study of Bali RS et al showed that among 179 patients of peptic ulcer perforation 150 were having duodenal ulcer and 29 were with gastric. ${ }^{13}$

\section{Post operative pain analysis}

In our study post operatively out of 30 patients 18 patients were presented with VAS 4, 11 patients were with VAS 2 and single patient presented with VAS 6 on post op day 1. On further follow up pain score reduced to 21 patients with VAS 0 and only 9 were with VAS 2 on post op day 3 and type of analgesia were chosen according to VAS score. The study of laparoscopic repair of perforated duodenal ulcer done by $\mathrm{S}$. Abdelaziem et al. ${ }^{16}$ All shows Post-operatively, VAS pain score ranged between 3 and 6 with a mean of 3.5 in the first postoperative day. Also, it ranged between 2 and 4 in the second post-operative day with a mean of 2.4. The patients needed post-operative parenteral narcotics for a period ranged between 1 and 2 days with a mean of 1.5 days.

\section{Post-operative complications}

Total post-operative complications noted in our study were 5 out of 30 patients $(16.66 \%)$ and most common complication in our study was trocar site infection which was seen in total 2 patients $(6.6 \%)$ and other common complications were sub-phrenic abscess, which was seen in 1 patient $(3.33 \%)$.

1 patient developed postoperative prolonged ileus while another 1 patient had post-operative subcutaneous emphysema.

25 patients $(83.33 \%)$ don't have any complications. Qazi AR et al shows post op complications in 25 laparoscopically operated patients of peptic ulcer perforation were recurrent perforation $(8 \%)$, port site infection (4\%) sub-phrenic abscess (4\%) Palanivelu C, et al had studied over 120 patients of peptic ulcer peroration which had undergone laparoscopic omental patch closure between 1995 to 2005 and found most common complication was trocar site infection which was present in 9 patients and total post operatively morbidity rate was only $7.5 \%$ while in our study post op morbidity is little higher $16.6 \% .^{17,18}$

\section{Conversion rate}

Out of total 30 patients 3 patients $(10 \%)$ needed to covert laparoscopic procedure into open procedure due to large size of perforation $(>10 \mathrm{~mm})$ in two patients while in one patient procedure converted into open due to intraoperative cardiovascular complication. Lunevicius $\mathrm{R}$ et al done laparoscopic closure in 51 patients in which 11 patients $(23.4 \%)$ underwent a conversion to open repair. ${ }^{19}$ According to this study ulcer perforation size $>4-10 \mathrm{~mm}$ is the only significant risk factor influencing the conversion rate.

\section{Post-operative course in the hospital}

In our study Out of thirty operated patients RT removal done on postoperative day 2 in 26 patients while in 2 patients RT removal done on day 4.

25 patients passed stool on postoperative day 3 while another 3 patients passed stool on postoperative day 4 and another 2 patients passed stool on postoperative day 5 and day 6.

The study of laparoscopic repair of perforated duodenal ulcer by S. Abdelaziem et al shows in the normal postoperative course, the nasogastric tube was removed after $24 \mathrm{~h}$ and oral fluids were resumed when bowel sounds become positive, whereas solid foods were allowed after toleration of oral fluids. ${ }^{16}$ Post-operative complications were recorded in the form of ileus.

\section{Post-operative diet resumption}

In the study of laparoscopic management of duodenal ulcer perforation by Palanivelu $\mathrm{C}$ et al in department of GI and minimal access surgery, Gem hospital oral fluid intake was permitted on the second postoperative day in 84 i.e. $70 \%$ patients and in 36 i.e. $30 \%$ on the third and fourth day. ${ }^{18}$

\section{Hospital stay}

In our study, hospital stay varied from 4-16 with an average hospital stay of 5.76 days. While in study of laparoscopic management of duodenal ulcer perforation by Palanivelu $\mathrm{C}$ et al the mean hospital stay was 5.8 days. $^{17}$

\section{CONCLUSION}

Laparoscopic repair of perforated peptic ulcer is safe and reliable technique. It gives the patient all the advantages 
of laparoscopic surgery with accepted post-operative morbidity and mortality rates. However, laparoscopic closure of the perforation is technically demanding. It should be considered as a good choice in the presence of reasonable laparoscopic skills and experience. It had less postoperative pain and reduced analgesic usages, shorter postoperative hospital stay and early return to oral feeding and normal daily activities.

Funding: No funding sources

Conflict of interest: None declared

Ethical approval: The study was approved by the institutional ethics committee

\section{REFERENCES}

1. Wyllie JH, Williams JA, Kennedy T, Clark C, Peter RF, Kirk RM, et al. Effect of Cimetidine on surgery of duodenal ulcer. Lancet 1981;317(8233):1307-8.

2. Simpson CJ, Lamont G, MacDonald I, Smith IS. Effect of cimetidine on prognosis after simple closure of perforated duodenal ulcer. Br J Surg. 1987;74:104-5.

3. Bertieff MJ, Lange JF. Perforated peptic ulcer disease: a review of history and treatment. Digestive surgery. 2010;27:161-9.

4. Hopkins RJ, Girardi LS, Turney EA. Relationship between both Helicobacter pylori eradication and reduced duodenal and gastric ulcer recurrence: a review. Gastroenterology. 1996;110:1244-52.

5. Mouret P, Francois Y, Vignal, Bartht JX, Lombard RP. Laparoscopic treatment of perforated peptic ulcer. Br J Surg. 1990;77:1006.

6. Nathanson LK, Easter DW, Cuschieri A. Laparoscopic repair/peritoneal toilet of perforated duodenal ulcer. Surg Endosc. 1990;4:232-3.

7. Druart ML, Van H R, Etienne J, Cadiere GB, Gigot JF, Legrand M, Laparoscopic repair of perforated peptic ulcer. a prospective multi-center clinical trial. Surg Endosc. 1997;11:1017-20.

8. Nathanson LK, Easter DW, Cuschieri A. Laparoscopic repair/peritoneal toilet of perforated duodenal ulcer. Surg Endosc. 1990;4(4):232-3.
9. Nathanson LK, Easter DW, Cuschieri A. Laparoscopic repair/peritoneal toilet of perforated duodenal ulcer. Surg Endosc. 1990;4(4):232-3.

10. Lau WY, Leow CK. History of perforated duodenal and gastric ulcers. World J Surg. 1997;21(8): 890-6.

11. Thorsen K, Soreide JA, Kvaloy JT, Glomsaker T, Søreide K. Epidemiology of perforated peptic ulcer: age and gender adjusted analysis of incidence and mortality. World J Gastroenterol. 2013;19(3):34754.

12. Sreeramulu PN, Venkatachalpahty TS, Supreet CS Prathima S. A comparative study of laparoscopic v/s open surgery of perforated duodenal ulcer. World J Laparosc Surg. 2013;6(1):11-4.

13. Singh RB, Verma S, Agarwal PN, Singh R, Talwar N. Clinical study-perforation peritonitis and the developing world; ISRN Surgery 2014. Article ID 105492, 4 pages.

14. Daley BJ. Peritonitis and abdominal sepsis clinical presentation. Available at: http:// emedicine.medscape.com /article/180234-overview. Accessed 18 January 2016.

15. Jhobta RS, Attri AK, Kaushik R, SAharma R, Jhobta A. Spectrum of perforation peritonitis in India: review of 504 consecutive cases. World J Emerg Surg. 2006;1:26.

16. Abdelaziem, Hashish MS, Suliman AN. Laparoscopic repair of perforated duodenal ulcer. Surgical Sci. 2015;6:80-90.

17. Qazi AR, Leghari AA, Shah PS. Laparoscopic repair in perforated peptic ulcer. Pak J Surg. 2011;27(3):173-6.

18. Palanivelu C, Jani K, Senthilnathan P. Laparoscopic management of duodenal ulcer perforation: is it advantageous? Ind J Gastroenterol. 2007;26(2):64-6.

19. Lunevicius R, Morkevicius M, Stanaitis J. Laparoscopic repair of perforated duodenal ulcer: early postoperative results and risk factors. 2004;40(11):1054-68.

Cite this article as: Deshmukh SB, Sharma K, Chawada MJ. Observational study of laparoscopic closure of peptic ulcer perforation in rural population. Int Surg J 2016;3:1273-7. 